\title{
PENGARUH STRATEGI PENYEIMBANGAN ANTARA AKTIVITAS PEKERJAAN DAN KELUARGA TERHADAP KESEJAHTERAAN KELUARGA SUBJEKTIF PADA PEREMPUAN BEKERJA DI BOGOR: Analisis Structural Equation Modelling
}

\author{
The Effect of Balancing Work and Families Strategies toward Subjective Family \\ Well-Being among Career Women in Bogor: Analysis of Structural Equation \\ Modelling \\ HERIEN PUSPITAWATI ${ }^{1^{*}}$ \\ ${ }^{1}$ Staf Pengajar Departemen Ilmu Keluarga dan Konsumen, Fakultas Ekolog \\ Manusia, Institut Pertanian Bogor, Jalan Lingkar Kampus IPB Dramaga, \\ Bogor 16680 serta Tim Pakar Gender Departemen Pendidikan Nasional-RI
}

\begin{abstract}
The main purpose of this research was to know the effect of working women's strategy in balancing between work and family towards the subjective family well-being. The respondents were working women who work in full-time and had a husband and a child or children. This was a cross sectional study which was performed among 50 working women in Bogor in March 2005. Almost all respondents were experienced in working because they have been working for about 15 years. The families of all respondents were in middleupper class families. The results showed that most of respondents performed the strategy of balancing between work and family activities. The overall subjective family well-being was measured by respondents' satisfaction towards their resources and conditions of physically, economically, socially, and psychologically. It was found that the strategic of women that tend to prioritize the family purposes had positive effect to the subjective family well-being.
\end{abstract}

Key words: balancing work, families strategies, SEM, subjective family well being

\section{PENDAHULUAN}

Pembangunan ekonomi nasional selama ini masih belum mampu meningkatkan kesejahteraan rakyat secara luas. Ketimpangan gender dalam tenaga kerja formal masih banyak terjadi di Indonesia diantaranya disebabkan adanya keterbatasan akses perempuan terhadap kesempatan menjadi pekerja di sektor formal. Perempuan lebih kecil kemungkinannya untuk bekerja, dan sebaliknya lebih besar kemungkinannya untuk tidak dipekerjakan. Perempuan cenderung mendapatkan kesulitan untuk memasuki pasar tenaga kerja karena adanya kekhawatiran sisi budaya bahwa perempuan akan meninggalkan tugasnya sehari-hari sebagai istri dan ibu rumah tangga.

\begin{abstract}
Kendala keterlibatan perempuan di pasar tenaga kerja diperparah lagi dengan meningkatnya tren masalah kemiskinan. Dalam rangka menanggulangi masalah kemiskinan keluarga ini, suatu strategi penyeimbangan antara aktivitas pekerjaan dan rumah tangga (balancing work and family strategies) yang dilakukan oleh perempuan bekerja adalah suatu cara untuk memenuhi tuntutan ekonomi secara nasional. Hal ini ditujukan agar tidak terjadi ketidakberfungsian keluarga yang dapat mengakibatkan hancurnya suatu keluarga atau karier atau keduanya. Apabila perempuan yang bekerja dapat menyeimbangkan antara pekerjaan dan keluarga maka akan terjadi peningkatan kesejahteraan keluarga baik dari segi ekonomi maupun non ekonomi sekaligus
\end{abstract}


meningkatkan kualitas sumberdaya manusia.

Strategi penyeimbangan antara pekerjaan dan keluarga membutuhkan beberapa pertimbangan, terutama yang berkaitan dengan keadaan keluarga seperti kondisi, jumlah, dan umur anak. Strategi penyeimbangan yang dilakukan oleh perempuan bekerja yang masih mempunyai balita pasti akan berbeda dengan perempuan bekerja yang sudah tidak mempunyai balita lagi. Secara garis besar, penelitian ini ingin membuktikan adanya pengaruh strategi penyeimbangan antara aktivitas pekerjaan dan keluarga pada perempuan bekerja terhadap kesejahteraan keluarga subjektif. Selanjutnya penelitian ini juga membuktikan bahwa perempuan mempunyai peran ganda yang sangat dibutuhkan bagi keluarga. Strategi penyeimbangan antara pekerjaan dan keluarga adalah satu-satunya strategi yang paling bijak dalam mencapai multitujuan (multi-purposes) keluarga dan individu perempuan, dengan mempertimbangkan adanya kepentingan pribadi dan keluarga melalui penerapan konsep opportunity cost dan pareto optimum.

Peran ganda perempuan menghasilkan ketegangan dan konflik (role strain) antara tuntutan pekerjaan dan keluarga. Konflik tersebut terbagi menjadi dua (Voydanoff \& Kelly 1984, dalam Kammeyer 1987). Pertama, yaitu beban berlebih, yang artinya adalah tuntutan dari dua sisi (pekerjaan dan rumah) melebihi kapasitas seseorang dalam menanganinya karena keterbatasan waktu dalam sehari untuk melakukan semua aktivitas yang cenderung tidak terbatas. Konflik peran ganda yang kedua adalah tumpang tindih (interference) yang artinya ada pekerjaan di kantor yang harus diselesaikan, sementara kewajiban keluarga juga harus dilaksanakan dalam waktu yang sama. Ketika keluarga dengan suami dan istri bekerja, masalah yang mendasar adalah keterbatasan waktu untuk melakukan kewajiban baik terhadap pekerjaan maupun keluarga yang semakin kecil dibandingkan dengan keluarga yang suaminya saja bekerja. Kata yang sering digunakan untuk mengkategorikan permasalahan ini adalah 'penyeimbangan' atau (balancing) (Kammeyer 1987). Oleh karena itu proses manajemen sumberdaya keluarga terutama berkaitan dengan manajemen waktu dan pekerjaan merupakan hal yang sangat penting bagi tercapainya tujuan keluarga (Puspitawati 1992, Winter \& Puspitawati 1993).

Strategi penyeimbangan antara pekerjaan dan keluarga membutuhkan terdapat aplikasi dari opportunity cost dan pareto optimum yang berupa pertimbangan-pertimbangan dalam mengalokasikan waktu untuk kegiatan produktif dan domestik. Opportunity cost di sini adalah adanya pengorbanan yang dilakukan karena mengerjakan atau memilih alternatif lain dengan mempertimbangkan risiko terendah (Nicholson 2001). Pareto optimum adalah meningkatnya kesejahteraan seseorang tanpa mengakibatkan orang lain menderita kerugian (Nicholson 2001).

Strober dan Weinberg (1980) dalam Puspitawati (1992) mengemukakan terdapatnya beberapa strategi yang potensial, ataupun kombinasi strategi yang dapat digunakan oleh perempuan bekerja diluar rumah untuk menggunakan waktunya secara ekonomis, yaitu: (1) Mengganti peralatan rumahtangga sehingga kegiatan rumahtangga dapat terlaksana baik secara kualitas maupun kuantitas, (2) Pekerjaan rumahtangga dilakukan oleh orang lain (pembantu rumahtangga, suami, atau anak) sehingga kegiatan rumahtangga dapat terlaksana baik secara kualitas maupun kuantitas, (3) Mengurangi kegiatan rumahtangga baik secara kualitas maupun kuantitas dan/atau melakukan kegiatan produktifnya secara intensif dan efektif ketika dihadapi masalah dengan kegiatan rumahtangga, (4) Mengurangi alokasi waktu, jika ada, untuk kegiatan amal dan kegiatan dalam komunitas kerja, dan (5) Mengurangi alokasi waktu untuk kegiatan santai dan/atau tidur.

Perempuan bekerja mempunyai alokasi waktu produktif dan domestik yang disebut dengan peran ganda. Secara umum, suami dan anak menganggap lazim pembagian tugastugas domestik rumahtangga pada semua perempuan (ibu), baik yang bekerja maupun yang tidak bekerja. Tidak peduli, apakah suami bekerja lama atau hanya sebentar, maka seorang perempuan (ibu) masih harus mengerjakan beberapa pekerjaan domestik rumahtangga (Suhendi \& Wahyu 2001). Sistem patriark 
mengatur bahwa peran pencari nafkah utama dengan istilah a main breadwinner dilakukan oleh suami (laki-laki) dan pengatur rumahtangga pada kegiatan domestik dengan istilah a homemaker dilakukan oleh perempuan (ibu). Seandainya perempuan berpartisipasi untuk mencari nafkah, maka perempuan dilabeli dengan predikat pencari nafkah tambahan atau a secondary breadwinner.

Secara umum tulisan ini bertujuan untuk mengetahui pengaruh strategi penyeimbangan antara aktivitas pekerjaan dan keluarga pada perempuan bekerja terhadap kesejahteraan keluarga subjektif dengan menggunakan analisis Structural Equation Modelling (SEM). Secara khusus tulisan ini bertujuan untuk mengetahui karakteristik keluarga dan karakteristik contoh serta untuk mengetahui pengaruh strategi penyeimbangan antara aktivitas pekerjaan dan keluarga pada perempuan bekerja terhadap kesejahteraan keluarga subjektif dengan menggunakan analisis Structural Equation Modelling (SEM).

Penelitian ini diharapkan dapat berguna untuk memberikan informasi kepada perempuan bekerja akan pentingnya menyeimbangkan antara aktivitas pekerjaan dan keluarga. Penelitian ini juga diharapkan dapat memberikan informasi yang penting bagi Pemerintah Daerah khususnya Pemda Kabupaten Bogor agar dapat memfasilitasi bentuk sosialisasi dan perlindungan bagi perempuan karier.

\section{METODE}

\section{Desain, Tempat, dan Waktu}

Penelitian ini menggunakan data sekunder dari penelitian Mayangsari (2005) dengan judul "Strategi Perempuan Bekerja dalam Menyeimbangkan antara Aktivitas Pekerjaan dan Rumah Tangga di Bogor" dengan menggunakan desain cross-sectional. Penelitian dilaksanakan di beberapa titik di Bogor, yaitu di IPB, SMUN 1 Bogor, PEMDA Kabupaten Bogor, Rumah Sakit Marzoeki Mahdi, dan Hotel Salak. Pengumpulan data dilaksanakan selama enam bulan yaitu bulan Desember 2004 sampai dengan Juli 2005. Kerangka pemikiran penelitian yang diuji dalam artikel ini tersaji pada Gambar 1.

\section{Cara Pengambilan Contoh dan Jenis Data}

Contoh penelitian ini adalah perempuan (ibu) bekerja dengan kriteria: (1) tingkatan manajerial kelas menengah ke atas, (2) berkeluarga serta mempunyai suami dan anak, dan (3) bersedia berpartisipasi dalam penelitian ini. Jumlah contoh adalah 50 orang perempuan bekerja. Jenis contoh dalam penelitian adalah pegawai negeri dan pegawai swasta. Pemilihan contoh dilakukan

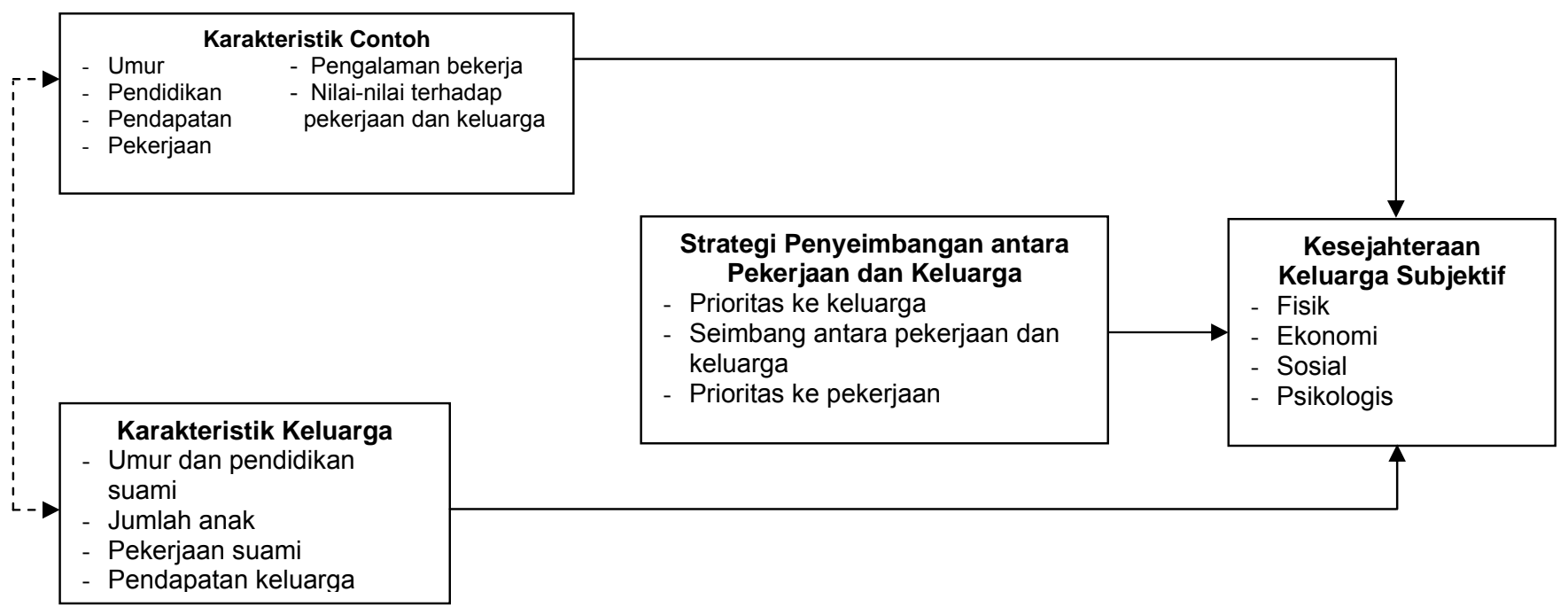

Gambar 1. Kerangka pemikiran pengaruh strategi perempuan bekerja dalam menyeimbangkan antara aktivitas pekerjaan dan keluarga terhadap kesejahteraan keluarga subjektif. 

dengan metode purposive sampling. Data yang dikumpulkan adalah data primer. Data primer meliputi karakteristik keluarga, karakteristik perempuan bekerja, strategi penyeimbangan, dan kesejahteraan keluarga subjektif.

\section{Pengolahan dan Analisis Data}

Data dianalisis secara deskriptif. Data karakteristik contoh dan keluarga, strategi penyeimbangan, dan kesejahteraan keluarga subjektif dikategorikan berdasarkan modus jawaban tiap responden untuk keseluruhan pertanyaan pada setiap variabel. Analisis hubungan antar variabel-variabel terkait dilakukan dengan menggunakan uji korelasi Spearman. Adapun analisis pengaruh strategi penyeimbangan antara aktivitas pekerjaan dan keluarga terhadap kesejahteraan keluarga subjektif pada perempuan bekerja dilakukan dengan menggunakan analisis Structural Equation Modelling (SEM).

\section{HASIL DAN PEMBAHASAN}

\section{Karakteristik Contoh dan Keluarga Contoh}

Diketahui bahwa rata-rata umur suami contoh adalah 42,16 tahun dengan kisaran antara 27 tahun sampai 58 tahun, sedangkan rata-rata umur contoh adalah 39,22 tahun dengan kisaran antara 25 tahun sampai 52 tahun. Sebagian besar contoh dan suaminya berpendidikan Perguruan Tinggi dengan tingkatan Strata 1 , yaitu sebesar $38 \%$ contoh dan $52 \%$ pada suaminya. Sebagian besar keluarga contoh yang diwawancara bekerja sebagai pegawai negeri, yaitu 96\% contoh dan 56\% pada suaminya. Proporsi terbesar keluarga contoh berasal dari keluarga kecil ( $\leq 5$ orang) sebesar $86 \%$, dan keluarga sedang (6 - 7 orang) sebesar $14 \%$ dengan rata-rata besar keluarga sebanyak hampir 5 orang per keluarga. Hampir setengah dari keluarga contoh (42\%) mempunyai balita dan lebih dari setengah keluarga contoh (54\%) mempunyai anak usia sekolah. Hanya seperlima dari keluarga contoh yang memiliki anak berusia lebih dari 20 tahun.

Data menunjukkan bahwa hampir tiga perempat keluarga contoh memiliki pembantu rumah tangga dengan kisaran upah seorang pembantu rumah tangga antara Rp 100.000,00 - Rp 375.000,00 dengan rata-rata upah per bulan sebesar Rp 211.250,00. Rata-rata pendapatan contoh adalah $\mathrm{Rp} 1.348 .030,00$ per bulan dengan kisaran antara $\mathrm{Rp} 400.000,00$ sampai Rp 4.000.000,00 per bulan, sedangkan rata-rata pendapatan suami contoh adalah Rp 1.986.000,00 per bulan dengan kisaran antara $\mathrm{Rp} 700.000,00$ Rp 8.000.000,00 per bulan. Rata-rata pendapatan per kapita keluarga contoh adalah Rp 610.267,02 per bulan dengan kisaran antara Rp 242.857,00 Rp 1.714.286,00 per bulan. Diketahui bahwa kontribusi pendapatan contoh terhadap pendapatan total keluarganya berkisar antara 25,1 - 50\%. Berdasarkan data, diketahui bahwa tidak ada satu pun dari keluarga contoh yang berada di bawah garis kemiskinan (Rp 137.929 menurut BPS 2005 dan Rp 659.500 sebagai Upah Minimum Regional (UMR) Kota Bogor tahun 2005) atau dengan kata lain seluruh keluarga contoh berada pada tingkatan status ekonomi menengah ke atas.

Rata-rata lama bekerja contoh adalah 15,90 tahun dengan kisaran antara 1 - 30 tahun. Sebaran terbesar lama bekerja contoh berkisar antara 16 20 tahun $(36 \%)$. Usia contoh pada saat pertama kali bekerja berkisar antara 19 28 tahun dengan rata-rata 23,32 tahun. Sebaran terbesar usia contoh pada saat pertama kali bekerja adalah 25 tahun (20\%). Sebaran lama jam kerja contoh antara 6 sampai 10 jam per hari dengan rata-rata 7,47 jam per hari. Sebesar 44\% contoh menggunakan kendaraan umum untuk menuju tempat kerja, 36\% contoh menggunakan kendaraan pribadi, 18\% contoh jalan kaki, dan hanya $2 \%$ contoh yang menggunakan bus kantor sebagai alat transportasi untuk pergi ke tempat kerja.

\section{Strategi Perempuan Bekerja dalam Menyeimbangkan antara Aktivitas Pekerjaan dan Keluarga}

Strategi penyeimbangan antara pekerjaan dan karir diperlukan untuk menjaga keharmonisan antara keluarga dan pekerjaan, sehingga tuntutan pekerjaan dan tuntutan keluarga dapat diselaraskan keduanya dan dapat terpenuhi secara bersama-sama. Strategi penyeimbangan ini tergantung dari persepsi dan kondisi nyata yang dialami contoh. Dalam menjalankan strategi 
tersebut, perempuan bekerja perlu melakukan tiga alternatif strategi, yaitu aktivitas yang memprioritaskan keluarga lebih tinggi daripada pekerjaan (dengan berbagai alasan keluarga), atau menyeimbangkan antara prioritas keluarga dan pekerjaan, atau aktivitas yang memprioritaskan pekerjaan lebih tinggi daripada keluarga (dengan berbagai alasan).

Pengabdian perempuan terhadap pekerjaan produktif akan menghasilkan pendapatan keluarga yang akhirnya berdampak pada penyesuaian pernikahan yang positif. Kontribusi perempuan dalam ekonomi keluarga menghasilkan peningkatan dalam bidang keuangan, kepemilikan barang mewah, standar hidup yang lebih tinggi dengan pencapaian rasa aman yang lebih baik sehingga berdampak pada peningkatan status sosial dari keluarga (Lasswell M \& Lasswell T 1987). Bagi perempuan yang bekerja diluar rumah, mengalami keadaan yang bertolak belakang, disatu sisi meningkatkan kesejahteraan ekonomi keluarga, tetapi di sisi lain penurunan fungsi dan peran sebagai ibu rumah tangga dalam menjalankan tugasnya dalam keluarga. Sebenarnya, selama perempuan yang bekerja di luar rumah masih berperan dalam pemenuhan kebutuhan anak melalui peran ganda perempuan, maka tidak akan terjadi disorganisasi keluarga. Sebaliknya, apabila peran dan fungsi sebagai ibu tidak dilaksanakan dengan baik oleh ibu yang bekerja di luar rumah, maka akan terjadi disorganisasi keluarga (Suhendi \& Wahyu 2001).

Dalam penelitian ini, terdapat dua jenis pernyataan dalam strategi perempuan bekerja yaitu mengenai persepsi (afektif) dan tindakan (praktek) contoh dalam menyeimbangkan antara pekerjaan dan keluarga. Kedua jenis pernyataan tersebut terbagi menjadi tiga kategori yaitu (1) pernyataan yang mengarah lebih ke kepentingan keluarga, (2) pernyataan yang mengarah ke strategi penyeimbangan antara pekerjaan dan keluarga, dan (3) pernyataan yang mengarah lebih ke kepentingan pekerjaan.

Strategi yang dipersepsikan contoh yang memprioritaskan keluarga (26\%) adalah mengutamakan keluarga (46\%) dalam setiap kesempatan yang ada seperti menelpon ke rumah pada saat sedang kerja $(18 \%)$, dan juga selalu meminta ijin suami apabila ada tugas ke luar kota $(66 \%)$. Strategi yang dipersepsikan contoh yang memprioritaskan pekerjaan $(10 \%)$ adalah mengutamakan kepentingan pekerjaan di atas kepentingan keluarga (2\%) dan tidak membawa anak ke tempat kerja (72\%). Adapun strategi yang dipersepsikan contoh yang menyeimbangkan antara pekerjaan dan keluarga (64\%) adalah masalah di kantor tidak dapat dicampuradukkan dengan masalah di rumah $(60 \%)$.

Jenis pernyataan kedua yaitu mengenai tindakan (praktek) contoh terhadap strategi bekerja. Tindakan contoh dengan strategi mementingkan keluarga $(2 \%)$ adalah tidak bekerja dan melanggar perintah atasan demi keluarga walaupun masih terdapat $40 \%$ yang kadang-kadang melakukannya. Tindakan contoh dengan strategi mementingkan pekerjaan $(6 \%)$, sebesar $28 \%$ menyatakan melakukan apapun demi kemajuan karier dan sering melewatkan acara keluarga karena urusan pekerjaan $(10 \%)$. Adapun tindakan contoh dengan strategi keseimbangan antara pekerjaan dan keluarga (92\%) bersepakat dengan suami untuk saling menjaga antara pekerjaan dan keluarga (78\%) dan tidak melakukan pekerjaan kantor pada hari libur $(24 \%)$.

Hasil dari Tabel 1 merupakan penjumlahan dari persepsi (afektif) dan tindakan (praktek) contoh terhadap strategi penyeimbangan aktivitas pekerjaan dan keluarga yang menunjukkan bahwa sebagian besar contoh melakukan keseimbangan antara pekerjaan dan keluarga (96\%). Hal ini dikarenakan pada umumnya contoh telah berpengalaman dalam mengatur kehidupannya untuk memenuhi antara tuntutan keluarga dan pekerjaan. Berpengalamannya contoh dalam menyeimbangkan antara pekerjaan dan keluarga tersebut disebabkan sebagian besar contoh telah bekerja selama lebih dari 15 tahun dan sebagian besar contoh pun berada pada tahap pemantapan dalam kehidupannya apabila dilihat dari kelompok umur. 
Tabel 1. Sebaran contoh berdasarkan strategi perempuan bekerja dalam menyeimbangkan antara aktivitas pekerjaan dan keluarga

\begin{tabular}{lrr}
\hline \multirow{2}{*}{ Strategi Perempuan Bekerja } & \multicolumn{2}{c}{ Jumlah } \\
\cline { 2 - 3 } & \multicolumn{1}{c}{$\mathbf{n}$} & \multicolumn{1}{c}{$\%$} \\
\hline Prioritas ke keluarga $(16-26,6)$ & 0 & 0,0 \\
Seimbang $(26,7-37,3)$ & $\mathbf{4 8}$ & $\mathbf{9 6 , 0}$ \\
Prioritas ke pekerjaan $(37,4-48)$ & 2 & 4,0 \\
\hline \multicolumn{1}{c}{ Total } & 50 & 100,0 \\
\hline
\end{tabular}

Selain itu, banyaknya contoh yang melakukan keseimbangan ini didukung oleh pendapat Poesposoetjipto (Saleha 2003) yang menyatakan bahwa seorang perempuan dalam budaya Timur lebih terpandang dan disegani apabila perempuan mampu membina keluarga yang sejahtera. Penelitian ini menunjukkan bahwa strategi penyeimbangan antara pekerjaan dan keluarga merupakan suatu keberhasilan perempuan yang berperan sebagai seorang istri/ibu dan sekaligus berperan sebagai pekerja profesional yang mampu menjaga keseimbangan antara tugas dan tanggung jawabnya dalam bisnis tempat bekerja.

\section{Kesejahteraan Keluarga Subjektif}

Kesejahteraan subjektif berdasarkan pendekatan Quality of Life adalah mengukur kepuasan atau kesenangan seseorang secara subjektif terhadap semua materi dan perilaku yang dilakukan untuk mencapai tujuan hidup. Kepuasan atau kesejahteraan ini dapat berbeda antara harapan dengan kenyataan dan dapat berbeda pada setiap orang. Menurut Guhardja et al. (1992), kepuasan merupakan output yang telah diperoleh akibat kegiatan suatu manajemen. Ukuran kepuasan ini dapat berbeda-beda untuk setiap individu atau bersifat subjektif. Puas atau tidaknya seseorang dapat dihubungkan dengan nilai yang dianut oleh orang tersebut dan tujuan yang diinginkan, nilai tersebut dapat berubah akibat banyaknya pengalaman. Menurut University of Toronto (2008) definisi kualitas hidup adalah:

"Quality of life is the degree to which a person enjoys the important possibilities of his/her life. Possibilities result from the opportunities and limitations each person has in his/her life and reflect the interaction of personal and environmental factors" (Quality of Life Research Unit, University of Toronto 2008).

Kesejahteraan keluarga subjektif yang diteliti adalah keadaan yang dirasakan (perceived) oleh contoh yang meliputi kesejahteraan fisik, ekonomi, sosial, dan psikologis. Kesejahteraan keluarga secara fisik terdiri dari keadaan kesehatan contoh dan keluarga; secara ekonomi terdiri dari keadaan keuangan, makanan, tempat tinggal, pakaian, dan materi/aset; secara sosial terdiri dari keadaan pendidikan, manajemen sumberdaya keluarga, pekerjaan, dan hubungan komunikasi antar sesama anggota keluarga serta komunikasi dengan keluarga besar dan lingkungan di luar keluarga; secara psikologis terdiri dari keadaan mental dan spiritual contoh dan keluarga.

Hasil menunjukkan bahwa persentase terbesar contoh merasa puas sampai sangat puas terhadap keadaan tempat tinggal keluarga $(50 \%)$, keadaan pekerjaan contoh (50\%), keadaan pekerjaan suami (56\%), hubungan atau komunikasi antara suami dan contoh (74\%), hubungan/komunikasi antara orang tua dengan anak (70\%), hubungan/komunikasi antara keluarga dengan keluarga besar (52\%), hubungan/komunikasi antara keluarga dengan tetangga (54\%), kelakuan/kepribadian anak (54\%), keadaan mental keluarga (56\%), keadaan mental contoh (50\%), dan keoptimisan keluarga menatap masa depan (48\%). Sementara itu, sebagian kecil contoh merasa sangat tidak puas terhadap keadaan tempat tinggal keluarga (4\%), keadaan tabungan keluarga $(6 \%)$, alat transportasi untuk kerja (2\%), dan aset pendukung pekerjaan (karier) yang ada di rumah, seperti handphone (HP), komputer, dan internet (2\%). Berdasarkan kategori kesejahteraan keluarga subjektif diketahui bahwa proporsi terbesar keluarga contoh $(76 \%)$ berada pada tingkat kesejahteraan keluarga subjektif sedang (Tabel 2) yang artinya keluarga contoh merasa cukup puas terhadap semua kesejahteraan fisik, sosial, ekonomi dan psikologi. 
Tabel 2. Sebaran keluarga contoh berdasarkan kategori kesejahteraan keluarga subjektif

\begin{tabular}{lrr}
\hline \multirow{2}{*}{$\begin{array}{c}\text { Kategori Kesejahteraan Keluarga } \\
\text { Subjektif }\end{array}$} & \multicolumn{2}{c}{ Jumlah } \\
\cline { 2 - 3 } & \multicolumn{1}{c}{$\mathbf{n}$} & \multicolumn{1}{c}{$\%$} \\
\hline Kurang $(30-70)$ & 0 & 0,0 \\
Sedang $(71-111)$ & $\mathbf{3 8}$ & $\mathbf{7 6 , 0}$ \\
Baik $(112-150)$ & 12 & 24,0 \\
\hline Total & 50 & 100,0 \\
\hline
\end{tabular}

Contoh yang memiliki tingkat kesejahteraan keluarga yang baik adalah contoh yang sangat puas terhadap kesehatan keluarga, keadaan keuangan keluarga, keadaan spiritual keluarga, dan keadaan pekerjaan suami. Sementara itu, contoh yang memiliki tingkat kesejahteraan keluarga sedang adalah contoh yang cukup puas terhadap hubungan komunikasi antara anggota keluarganya, keadaan pakaian keluarga, dan keadaan mental keluarga. Adapun contoh yang memiliki tingkat kesejahteraan keluarga yang kurang adalah contoh yang tidak puas terhadap keadaan tempat tinggal dan tabungan keluarga, alat transportasi untuk kerja, dan aset pendukung pekerjaan (karier) yang ada di rumah.

\section{Hubungan Strategi Penyeimbangan antara Pekerjaan dan Keluarga terhadap Kesejahteraan Keluarga Subjektif}

Hasil penelitian menunjukkan bahwa terdapat hubungan yang nyata antara strategi perempuan bekerja dalam menyeimbangkan pekerjaan dan keluarga dengan kesejahteraan keluarga subjektif $(p<0,01)$ dan bersifat negatif sebesar $39 \%$. Hubungan tersebut menggambarkan bahwa tingkat kesejahteraan keluarga subjektif contoh semakin meningkat apabila contoh lebih memprioritaskan strateginya ke kepentingan keluarga daripada kepentingan pekerjaan. Hal ini terkait dengan tugas utama perempuan sebagai seorang istri dan ibu. Hal ini dikarenakan keluarga adalah suatu organisasi terkecil yang memerlukan adanya kejelasan tugas dari masing-masing anggota keluarga. Apabila satu anggota melalaikan tugasnya maka organisasi tersebut akan berusaha untuk mempertahankan keutuhan, karena beban di dalam organisasi tersebut yang dapat menyebabkan ketidaknyamanan bagi anggota keluarga lainnya. Akan tetapi, apabila seorang anggota membantu tugas anggota lain tanpa melalaikan tugas utamanya, maka beban yang ditanggung oleh organisasi dapat berkurang. Walaupun terkadang bebannya bertambah, hal itu dapat diatasi dengan cara menyeimbangkan tugas ganda seorang perempuan dengan tidak melalaikan salah satu tugas lainnya.

Hasil pada Tabel 3 menunjukkan bahwa contoh yang melakukan keseimbangan antara aktivitas pekerjaan dan rumah tangga ternyata tidak membawa kesejahteraan keluarganya berada pada posisi yang baik dari segi fisik dan ekonomi. Akan tetapi, contoh tersebut membawa kesejahteraan psikologis keluarga yang baik. Hal ini disebabkan contoh yang melakukan keseimbangan adalah contoh dengan kondisi mental yang baik, sehingga berdampak pula pada keadaan psikologis keluarga. Sementara itu, pada contoh yang lebih memprioritaskan pekerjaan daripada keluarga juga tidak membawa kesejahteraan keluarga dari segi fisik dan ekonomi berada pada posisi yang baik. Akan tetapi, terdapat setengah dari contoh tersebut (50\%), yang kesejahteraan keluarganya berada pada kategori baik dari segi sosial dan psikologis. Apabila dilihat dari hasil uji korelasi Spearman, justru contoh yang lebih mengutamakan strateginya untuk kepentingan keluarga memiliki tingkat kesejahteraan keluarga yang semakin baik dari segi fisik $\left(-0,272^{*}, p=0,05\right)$, ekonomi $\quad\left(-0,278^{*}, \quad p=0,05\right)$, sosial $\left(-0,353^{* *}, \quad p=0,01\right)$, dan dari segi psikologis $\left(-0,312^{*}, p=0,05\right)$. 
Tabel 3. Sebaran persentase contoh berdasarkan strategi penyeimbangan antara pekerjaan dan keluarga terhadap kesejahteraan keluarga subjektif

\begin{tabular}{|c|c|c|c|c|c|c|c|c|c|c|}
\hline \multirow{3}{*}{$\begin{array}{c}\text { Strategi } \\
\text { Penyeimbangan } \\
\text { antara Pekerjaan } \\
\text { dan keluarga } \\
\end{array}$} & \multicolumn{10}{|c|}{ Kesejahteraan Keluarga Subjektif } \\
\hline & \multicolumn{2}{|c|}{ Fisik } & \multicolumn{2}{|c|}{ Ekonomi } & \multicolumn{2}{|c|}{ Sosial } & \multicolumn{2}{|c|}{ Psikologis } & \multicolumn{2}{|c|}{ Total } \\
\hline & $\mathbf{R}$ & $\mathbf{T}$ & $\mathbf{R}$ & $\mathbf{T}$ & $\mathbf{R}$ & $\mathbf{T}$ & $\mathbf{R}$ & $\mathbf{T}$ & $\mathbf{R}$ & $\mathbf{T}$ \\
\hline $\begin{array}{l}\text { Cenderung ke } \\
\text { Keluarga }\end{array}$ & 0,0 & 0,0 & 0,0 & 0,0 & 0,0 & 0,0 & 0,0 & 0,0 & 0,0 & 0,0 \\
\hline Seimbang & 52,1 & 47,9 & 58,3 & 41,7 & 50,0 & 50,0 & 47,9 & 52,1 & 54,2 & 45,8 \\
\hline $\begin{array}{l}\text { Cenderung Ke } \\
\text { Pekerjaan }\end{array}$ & 100,0 & 0,0 & 100,0 & 0,0 & 100,0 & 100,0 & 50,0 & 50,0 & 100,0 & 0,0 \\
\hline Total & 54,0 & 46,0 & 60,0 & 40,0 & 50,0 & 50,0 & 48,0 & 52,0 & 56,0 & 44,0 \\
\hline
\end{tabular}

\section{Pengaruh Strategi Penyeimbangan antara Pekerjaan dan Keluarga terhadap Kesejahteraan Keluarga Subjektif}

Hasil pada Gambar 2 menunjukkan bahwa angka pada nilai GFI (Goodness of Fit Index) adalah 0,75 dan nilai CFI (Comparative of Fit Index) adalah 0,55. Oleh karena itu, diketahui bahwa modelmodel yang disusun tersebut menurut Bollen (1989) masih dapat dikatakan cukup cocok atau fit dengan data yang dikumpulkan, meskipun masih tergolong sangat rendah mengingat jumlah sampel yang hanya 50 responden.

Hasil analisis menunjukkan bahwa kesejahteraan keluarga subjektif terdiri atas indikator kesejahteraan fisik $\left(\lambda y=1,00^{*}, \quad p=0,05\right)$, indikator kesejahteraan ekonomi $\left(\lambda y=0,54^{*}, \quad p=0,05\right)$, indikator kesejahteraan sosial $\left(\lambda y=0,51^{*}\right.$, $p=0,05)$, dan indikator kesejahteraan psikologi $\left(\lambda y=0,54^{*}, p=0,05\right)$. Berdasarkan uji reliabilitas Cronbach Alpha, diketahui bahwa assessment kesejahteraan keluarga subjektif diukur berdasarkan 30 item pertanyaan dengan skala likert 1 (sangat tidak puas) sampai 5 (sangat puas) menunjukkan tingkat reliabilitasnya adalah 0,94 . Sementara itu, Cronbach Alpha untuk assessment strategi penyeimbangan pekerjaan dan keluarga diukur berdasarkan 16 item pertanyaan dengan skala likert 1 (tidak pernah) sampai 3 (sering) adalah 0,55.

Selanjutnya, hasil menunjukkan bahwa strategi penyeimbangan antara aktivitas pekerjaan dan keluarga pada perempuan bekerja berpengaruh negatif signifikan $\left(\beta=-0,27^{\star}\right)$ terhadap kesejahteraan keluarga subjektif (hasil SEM sama dengan hasil uji korelasi Spearman). Hal ini berarti bahwa strategi yang cenderung memprioritaskan pada keperluan keluarga pada perempuan bekerja berpengaruh secara positif terhadap kesejahteraan keluarga subjektif baik fisik, sosial, ekonomi, maupun psikologi. Sehingga, didapatkan hasil adanya pengaruh negatif nyata $(p<0,01)$ antara strategi penyeimbangan dengan kesejahteraan keluarga subjektif yang berarti bahwa semakin contoh memprioritaskan kepentingan pekerjaan yang lebih besar dari pada keluarga, maka berpengaruh terhadap penurunan tingkat kesejahteraan keluarga subjektif baik dari segi fisik, sosial, maupun psikologis. Sebaliknya, apabila contoh semakin memprioritaskan kepentingan keluarga lebih besar daripada kepentingan pekerjaan, maka berpengaruh terhadap peningkatan kesejahteraan keluarga subjektif baik dari segi fisik, sosial, maupun psikologis.

\section{Pembahasan Umum}

Strategi penyeimbangan antara aktivitas pekerjaan dan rumah tangga yang dilakukan oleh perempuan bekerja adalah suatu cara untuk memenuhi tuntutan pekerjaan dan tuntutan keluarga sehingga segala sesuatunya berjalan lancar. Hal ini ditujukan agar tidak terjadinya disfungsi keluarga yang dapat mengakibatkan hancurnya suatu keluarga. Apabila perempuan bekerja dapat menyeimbangkan antara kepentingan pekerjaan dan keluarga maka akan terjadi peningkatan kesejahteraan keluarga subjektif baik dari segi ekonomi maupun non ekonomi.

Strategi penyeimbangan antara kepentingan pekerjaan dan keluarga membutuhkan beberapa pertimbangan, terutama yang berkaitan dengan keadaan keluarga seperti jumlah dan umur anak. Selain itu, dalam penyeimbangan tersebut 


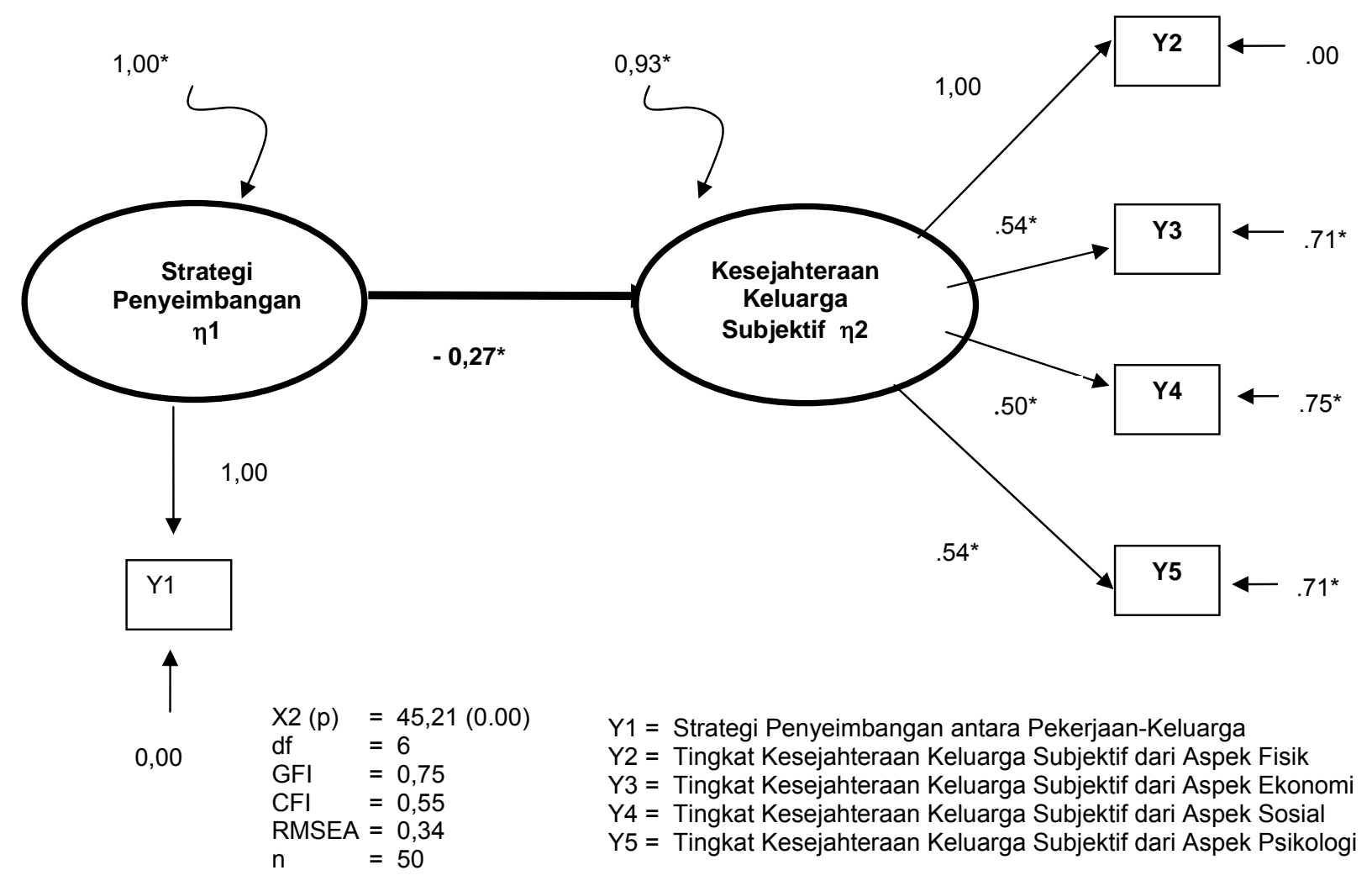

Gambar 2. Pengaruh strategi penyeimbangan pekerjaan-keluarga pada perempuan terhadap kesejahteraan keluarga subjektif.

terdapat aplikasi dari opportunity cost dan pareto optimum yang berupa pertimbangan-pertimbangan dalam mengalokasikan waktu untuk kegiatan produktif dan domestik. Opportunity cost di sini adalah adanya pengorbanan yang dilakukan karena mengerjakan atau memilih alternatif lain yang memiliki risiko terendah (Nicholson 2001). Hal yang dikorbankan oleh contoh adalah alokasi waktu untuk kegiatan domestik karena semakin bertambahnya jumlah anak yang dimiliki dan semakin meningkatnya umur anak contoh maka semakin kecil risiko apabila dikurangi alokasi waktunya. Dengan semakin bertambahnya jumlah anak dan umur anak, maka contoh yang seharusnya menjalankan tugasnya sebagai seorang ibu kini menjadi beralih ke pekerjaan di kantor sehingga waktu untuk kegiatan produktif pun bertambah. Hal ini disebabkan dengan semakin meningkatnya jumlah anak maka jumlah anggota keluarga pun meningkat sehingga kebutuhan hidup keluarga akan meningkat pula. Umur anak yang semakin meningkat juga menyebabkan contoh mengurangi kegiatan domestiknya dan meningkatkan kegiatan produktif, karena dengan semakin meningkatnya umur anak maka anak tersebut akan semakin mandiri sehingga campur tangan orang tua akan semakin berkurang.

Sementara itu, pareto optimum adalah meningkatnya kesejahteraan seseorang tanpa mengakibatkan orang lain menderita (Nicholson 2001). Aplikasinya pada perempuan bekerja adalah bahwa perempuan bekerja ingin meningkatkan kegiatan produktifnya dan mengurangi kegiatan domestiknya tanpa harus mengorbankan kepentingan keluarga, yaitu kebahagiaan dan kepuasan hidup suami dan anakanaknya. Pada penelitian ini didapatkan bahwa contoh tidak mengabaikan 
tugasnya sebagai seorang ibu/istri walaupun kontribusi contoh terhadap kesejahteraan ekonomi keluarganya meningkat.

Apabila dikaitkan dengan kesejahteraan keluarga subjektif yang dirasakan oleh contoh, ternyata dengan melakukan penyeimbangan antara kepentingan pekerjaan dan keluarga maka contoh akan merasa sangat puas terhadap kesejahteraan subjektif sosial dan psikologis keluarganya. Hal ini berarti meskipun contoh bekerja di luar rumah, komunikasi antara contoh dengan anggota keluarga tetap berjalan lancar begitupun dengan keadaan mental/spiritual keluarga.

Secara garis besar, penelitian ini menguatkan argumen-argumen dari peneliti-peneliti sebelumnya (Puspitawati 1992; Winter \& Puspitawati 1993) bahwa manajemen sumberdaya keluarga terutama berkaitan dengan manajemen waktu dan pekerjaan merupakan hal yang sangat penting bagi tercapainya tujuan keluarga. Selanjutnya penelitian ini juga membuktikan bahwa perempuan mempunyai peran ganda yang sangat dibutuhkan bagi keluarga untuk mewujudkan kesejahteraan keluarga subjektif. Strategi penyeimbangan antara kepentingan pekerjaan dan keluarga adalah satu-satunya strategi yang paling bijak dalam mencapai multi-tujuan (multipurpose) keluarga dan individu perempuan, dengan mempertimbangkan adanya kepentingan pribadi dan keluarga melalui penerapan konsep opportunity cost dan pareto optimum.

\section{Keterbatasan Penelitian}

Penelitian ini hanya menggunakan 50 contoh secara tidak acak serta tidak distratifikasi. Mengingat keterbatasan metode, maka hasil dari kesimpulan dari penelitian ini tidak dapat digeneralisasikan untuk seluruh perempuan bekerja. Namun demikian, hasil dari penelitian dapat memberikan kontribusi baik pada praktisi maupun peneliti di bidang gender dan keluarga.

\section{KESIMPULAN DAN SARAN}

\section{Kesimpulan}

Hasil penelitian terhadap perempuan bekerja di wilayah Bogor menunjukkan sebagian besar tingkat pendidikan contoh dan suami berada pada jenjang Strata 1, memiliki pekerjaan sebagai pegawai negeri dengan rata-rata besar anggota keluarga adalah 5 orang. Sekitar setengah dari jumlah contoh memiliki anak usia sekolah dan tiga perempat dari jumlah contoh memiliki pembantu rumah tangga. Rata-rata pendapatan keluarga per kapita adalah Rp 610.267,02 per bulan. Rata-rata lama bekerja contoh adalah 15,90 tahun dengan rata-rata lama jam kerja sebesar 7,47 jam per hari.

Hampir seluruh contoh melakukan keseimbangan antara kepentingan pekerjaan dan keluarga yang ditunjukkan oleh sebagian besar contoh dengan masa kerja lebih dari 15 tahun. Didapatkan hasil adanya pengaruh negatif nyata $(p<0,01)$ antara strategi penyeimbangan dengan kesejahteraan keluarga subjektif yang berarti bahwa semakin contoh melakukan strategi yang memprioritaskan kepentingan pekerjaan lebih besar dari pada kepentingan keluarga, maka berpengaruh terhadap penurunan tingkat kesejahteraan keluarga subjektif baik fisik, sosial, maupun psikologis. Sebaliknya, apabila contoh semakin melakukan strategi yang memprioritaskan kepentingan keluarga lebih besar daripada kepentingan pekerjaan, maka berpengaruh terhadap peningkatan kesejahteraan keluarga subjektif baik fisik, sosial, maupun psikologis.

\section{Saran}

Perempuan bekerja memiliki peran ganda baik sebagai ibu rumah tangga maupun sebagai pekerja profesional di bidangnya. Demi mempertahankan kedua peran ganda tersebut, disarankan untuk membuat upaya penyeimbangan antara kepentingan keluarga dan pekerjaan yang disesuaikan dengan tahapan dan kebutuhan keluarga. Perempuan yang mempunyai anak balita, disarankan untuk memiliki pembantu rumah tangga atau pengganti pengasuhan yang dilakukan oleh ibu demi untuk melindungi dan memelihara anaknya. Peran suami dan keluarga besar sangat diperlukan dalam membantu perempuan untuk memelihara peran ganda antara pekerjaan dan keluarganya. Selain itu juga perlu adanya penelitian lanjutan mengenai perbedaan strategi penyeimbangan dan hubungannya dengan kesejahteraan keluarga pada perempuan yang 
mempunyai suami bekerja di luar kota atau di dalam kota, juga antara perempuan dari keluarga tunggal dan keluarga utuh. Penelitian strategi penyeimbangan dan pengaruhnya terhadap kesejahteraan keluarga objektif berdasarkan indikator sosial ekonomi juga perlu untuk dilakukan.

\section{DAFTAR PUSTAKA}

[BPS] Badan Pusat Statistik. 2005. Kota Bogor dalam Angka.

Guhardja S, Herien P, Hartoyo dan D Hastuti. 1992. Diktat Manajemen Sumberdaya Keluarga. Bogor: Jurusan Gizi Masyarakat dan Sumberdaya Keluarga.

Kammeyer KCW. 1987. Marriage and Family: a Foundation for Personal Decisions. Massachusetts: Allyn \& Bacon.

Lasswell M, Lasswell T. 1987. Marriage and the Family. California: Wadsworth Publishing Company.

Mayangsari EP. 2005. Strategi Perempuan Bekerja Dalam Menyeimbangkan Antara Aktivitas Pekerjaan dan Rumah Tangga Di Bogor [skripsi]. Bogor: Fakultas Pertanian, Institut Pertanian Bogor.

\footnotetext{
* Korespondensi :

Departemen IImu Keluarga dan Konsumen

Fakutas Ekologi Manusia IPB

Jl. Lingkar Kampus IPB Dramaga 16680

Telp : +62-251 8628303

Email : herien_puspitawati@ymail.com
}

Nicholson W. 2001. Teori Ekonomi Mikro: Prinsip Dasar dan Pengembangannya (Deliarnov, penerjemah). Jakarta: RajaGrafindo Persada.

Puspitawati H. 1992. Time Management Strategies Used in Households in Which Income is Generated at Home [tesis]. Major Family Environment, Department of Human Development and Family Studies. College of Family and Consumer Science. lowa State University.

Saleha Q. 2003. Manajemen Sumberdaya Keluarga: Suatu Analisis Gender dalam Kehidupan Keluarga Nelayan di Pesisir Bontang Kuala, Kalimantan Timur [tesis]. Bogor: Program Pascasarjana, Institut Pertanian Bogor.

Suhendi H, Wahyu R. 2001. Pengantar Studi Sosiologi Keluarga. Bandung: Pustaka Setia.

University of Toronto-Canada. 2008. Quality of Life Research Unit. Notes on "Quality of Life". http//www.gdrc.org. [25 Maret 2008].

Winter M, Puspitawati H. 1993. Time Management Strategies Used By Households with Home-Based Work. Journal of Family and Economic Issues, 14 (1), Spring 1993. 

